University of Nebraska - Lincoln

DigitalCommons@University of Nebraska - Lincoln

U.S. Department of Veterans Affairs Staff

Publications

U.S. Department of Veterans Affairs

$12-12-2003$

\title{
Understanding Threats to Scientific Openness
}

James B. Petro

Stanford University School of Medicine, jbpetro@hotmail.com

David A. Relman

Stanford University School of Medicine, relman@stanford.edu

Follow this and additional works at: https://digitalcommons.unl.edu/veterans

Petro, James B. and Relman, David A., "Understanding Threats to Scientific Openness" (2003). U.S.

Department of Veterans Affairs Staff Publications. 22.

https://digitalcommons.unl.edu/veterans/22

This Article is brought to you for free and open access by the U.S. Department of Veterans Affairs at DigitalCommons@University of Nebraska - Lincoln. It has been accepted for inclusion in U.S. Department of Veterans Affairs Staff Publications by an authorized administrator of DigitalCommons@University of Nebraska - Lincoln. 


\section{Understanding Threats to Scientific Openness}

\author{
James B. Petro* and David A. Relman
}

so may rely upon dual-use information.

With publications from nearly 50 years ago, a marginally skilled terrorist could produce a crude agent for use in a limited bioterror attack. However, using more recently published research findings and procedures, casualty rates associated with such an incident would increase dramatically. Thus, our inability to restrict access to already published research in no way absolves the scientific and national security

tory of biological warfare. The site also contained over 20 vintage research articles and medical publications from U.K. journals of the 1950s and ' 60 s that provided a method for isolating, culturing, identifying, and producing bacteria, including Bacillus anthracis and Clostridium botulinum. Handwritten letters and BW primers found together at the same site suggest that al-Qaida's BW initiative included recruitment of individuals with Ph.D.-level expertise who supported planning and acquisition efforts by their familiarity with the scientific community. When specific information was not available in print, alQaida scientists ap-

parently took advantage of symposia where they could obtain tips and techniques directly from unsuspecting researchers (2). The letter shown (figure, above) reveals plans to acquire bacterial strains, vaccines, production equipment, training, and expertise. The scientific community needs to be aware of this kind of activity. Qaida in its efforts to establish a biological warfare (BW) program. Individuals involved in this effort apparently relied on scientific research and information obtained collegially from public and private sources (see figure, above right) (2).

Books found at the camp describe Statesponsored BW activities and outline the his-

J. B. Petro is with the Joint Military Intelligence College, Bolling AFB, Washington, DC 20340-5100; D. A. Relman is with the Departments of Microbiology \& Immunology, and of Medicine, Stanford University School of Medicine, Stanford, CA 94305, and with Veterans Affairs, Palo Alto Health Care System, Palo Alto, CA 94304, USA.

*To whom correspondence should be addressed. E-mail: jbpetro@hotmail.com

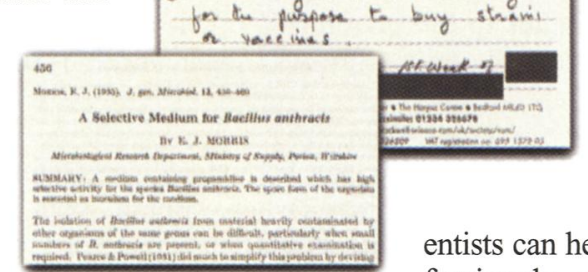
communities of our responsibility to address future findings of concern.

The life science community should take the lead in partnering with national security professionals to draft guidelines for identifying research of concern and weighing the benefits to national security against the cost to open communication of future life science discovery (5). Furthermore, scientists can help ensure security professionals maintain a working knowledge of cutting-edge tools and data with national security implications. Such a partnership should include scientists who are given security clearance and national security participants that represent the spectrum of relevant agencies with a strong background and training in the life sciences (6).

\section{References and Notes}

1. Testimony of Director of Central Intelligence G. J. Tenet Before the Senate Select Committee on Intelligence (as prepared for delivery) 6 February 2002. http://www.cia.gov/cia/public_affairs/speeches/

2. Research papers, clinical studies, and excerpts from academic texts related to Bacillus anthracis, Clostridium species, Yersinia pestis, and other bacterial and viral pathogens. A list of these materials and a sample FOIA request for full documents are available at the URL below.

3. M. R. Gordon, New York Times, 23 March 2002, p. A1.

4. W. S. Carus, Bioterrorism and Biocrimes: The Illicit Use of Biological Agents Since 1900 (Center for Counterproliferation Research, National Defense University, Washington, DC, 2001), pp. 7-16.

5. U.S. National Academy of Sciences, "Biotechnology research in an age of terrorism: Confronting the 'dual use' dilemma" (National Academies Press, Washington, DC, in press); www.nap.edu/catalog/ 10827.html?onpi_newsdoc100803.

6. Views expressed do not reflect the official policy or position of the Joint Military Intelligence College, the Department of Defense, or the U.S. Government.

Supporting Online Material

www.sciencemag.org/cgi/content/full/302/5652/1898/DC1 
Robert Richardson

Defense Intelligence Agency

ISM-1 (FOIA)

Washington, DC 20340-5100

Re: Freedom of Information Act Request

Dear Mr. Richardson:

This is a request under the Freedom of Information Act, 5 U.S.C. Sec. 552.

I request that a copy of the following documents [or documents containing the following information] be provided to me: al-Qaida documents discovered by U.S. forces in Afghanistan that pertain to the research materials referenced in the Petro and Relman article "Understanding Threats to Scientific Openness" published in the 12 December 2003 issue of Science. Should portions of these documents be deemed too sensitive to be released, I am requesting all releasable materials to be appropriately appended and provided.

In order to help determine my status to assess fees, you should know that I am xxx (Requestors should indicate their professional status and reason for requesting the material).

I am aware that I am entitled to make this request under the Freedom of Information Act, and if your agency response is not satisfactory, I am prepared to make an administrative appeal. Please indicate to me the name of the official to whom such an appeal should be addressed.

I am aware that if my request is denied I am entitled to know the grounds for this denial.

I request a waiver of all fees for this request. Disclosure of the requested information to me is in the public interest because it is likely to contribute significantly to public understanding of the operations or activities of terrorist exploiters and is not primarily in my commercial interest.

Sincerely,

Name

Address

City, State, ZIP

Phone number (optional) 


\section{Selected Document References:}

Darlow, HM, and Pride, NB. (1969). Serological diagnosis of anthrax. Lancet ii(7617):430.

Doi, H, et al. (1996). Hepatitis C virus (HCV) subtype prevalence in Chiang Mai, Thailand, and identification of novel subtypes of HCV major type 6. J. Clin. Microbiol. 34(3):569-574.

Green, DM, and Jamieson, WM. (1958). Anthrax and bone-meal fertilizer. Lancet ii:153154.

Hobbs, G, Roberts, TA, and Walker, PD. (1965). Some observations on OS variants of Clostridium botulinum type E. J. Appl. Bacteriol. 28(1):147-152.

Mangold, T, and Goldberg, J. (1999). Plague Wars: The Terrifying Reality of Biological Warfare. MacMillan, Great Britain.

Morris, EJ. (1955). A selective medium for Bacillus anthracis. J. Gen. Microbiol. 13:456-460.

Pearce, TW, and Powell, EO. (1951). A selective medium for Bacillus anthracis. J. Gen. Microbiol. 5:387-390

Roberts, TA. (1965). Sporulation of Clostridium botulinum type E in different culture media. J. Appl. Bacteriol 28(1):142-146.

Roberts, TA, and Ingram, M. (1965). The resistance of spores of Clostridium botulinum type E to heat and radiation. J. Appl. Bacteriol. 28:125.

Semple, AB, and Hobday, TL. (1959). Control of anthrax: Suggestions based on survey of imported hides. Lancet ii (3 October): 507-508

Stanley, JL, and Smith H (1961). Purification of factor I and recognition of a third factor of the anthrax toxin. J. Gen. Microbiol. 26:49-66.

Thorne, CB, and Belton, FC. (1957). An agar-diffusion method for titrating Bacillus anthracis immunizing antigen and its application to a study of antigen production. J. Gen. Microbiol. 17:505-516.

Wang, CH, et al. (1996). Immune response to hepatitis A virus capsid proteins after infection. J. Clin. Microbiol. 34(3):707-713. 


\section{Selected Supplementary References from Handwritten Notes Recovered on Site:}

Ajl, SJ, Kadis, S, and Montie, TC. (1970) Microbial Toxins. Academic Press, New York.

Anderson, RM, and May, RM. (1991). Infectious Diseases of Humans: Dynamics and Control. Oxford University Press, Oxford.

Batty, I and Walker, PD. (1965). Colonial morphology and fluorescent labelled antibody staining in the identification of species of the genus Clostridium. J. Appl. Bacteriol.

28:112.

Brachman, PS, Plotkin, SA, Bumford, FH, and Atchison, MM. (1960). An epidemic of inhalation anthrax: The first in the twentieth century. II. Epidemiology. Am. J. Hyg. 72:623.

Clarke, R. (1968). We All Fall Down: The Prospects of Biological and Chemical Warfare. Penguin Books, London.

Hodgkiss, W, and Ordal, ZJ. (1966). The morphology of the spore of some strains of Clostridium botulinum type E. J. Bacteriol. 91:2031-2036.

Keppie, J, Cocking, EC, Witt, K, and Smith, H. (1960). The chemical basis of the virulence of Pasteurella pestis. III. An immunogenic product obtained from Past. pestis that protects both guinea pigs and mice. Br. J. Exp. Pathol. 41:577-585.

Knisley, RF. (1966). Selective medium for Bacillus anthracis. J. Gen. Microbiol. 13:456.

Knisely, RF, Swaney, LM, and Friedlander, H. (1964). Selective media for the isolation of Pasteurella pestis. J. Bacteriol. 88:491-496.

Miller, JK. Human anthrax in New York state. N.Z. Med. J. 61:2046-2053.

Murphy, S, Hay, A, and Rose, S. (1986). No Fire, No Thunder: The Threat of Chemical and Biological Weapons. Pluto Press, London.

Proceedings of the Conference on Airborne Infection. (1961). Bacteriol. Rev. 25:173382.

Riemann, H. (1969). Botulism Types A, B, and F in Foodborne Infections and Intoxications. Edited by H Rieman. Academic Press, New York.

Roberts, B. (1993). Biological Weapons: Weapons of the Future. Significant Issues Series XV(1). Center for Strategic and International Studies. Washington, DC.

Rothschild, JH. (1964). Tomorrow's Weapons. McGraw-Hill, New York. 
Smith, H (1988). The development of studies on the determinants of bacterial pathogenicity. J. Comp. Pathol. 98:253-73.

Walgate, R. (1990). Miracle of Menace? Biotechnology and the Third World. The Panas Institute, London.

William, P, and Wallace, D. (1989). Unit 731: The Japanese Army's Secret of Secrets. Hodder and Stoughton, London.

World Health Organization (1970) Expert Committee on Plague, $4^{\text {th }}$ Report. World Health Org. Tech. Rep. Ser. (no. 447). 